\title{
Micropropagation on multiplication of native greenberries in South of Brazil
}

\author{
Micropropagação na multiplicação de amoreiras-verdes nativas do Sul do Brasil \\ Micropropagación en la multiplicación de moras verdes originarias del sur de Brasil
}

Received: 01/08/2021 | Reviewed: 01/10/2021 | Accept: 01/12/2021 | Published: 01/15/2021

Thábata Cristina Faxina De Aguiar
ORCID: https://orcid.org/0000-0003-4412-5916
Universidade do Estado de Santa Catarina, Brazil
E-mail: Thabata_biologia@hotmail.com
Murilo Dalla Costa
ORCID: https://orcid.org/0000-0001-7422-1883
Orate
E-mail: Murilodc@epagri.sc.gov.br
Pedro Boff
Empresa de Pesquisa Agropecuária e Extensão Rural de Santa Catarina, Brail
ORCID: https://orcid.org/0000-0002-9041-5503
Empresa de Pesquisa Agropecuária e Extensão Rural de Santa Catarina, Brazil
E-mail: Boff.pedro@yahoo.com.br
Mari Inês Carissimi Boff
ORCID: https://orcid.org/0000-0003-1700-8837
Universidade do Estado de Santa Catarina, Brazil
E-mail: Mari.boff@udesc.br

\begin{abstract}
Rubus brasiliensis and Rubus erythroclados are commonly known as greenberries. This work aimed to test in vitro micropropagation protocols to greenberries. The multiplication experiment was conducted using BAP at concentrations $1 \mathrm{mg} \mathrm{L}^{-1}, 2 \mathrm{mg} \mathrm{L}^{-1}$ and $3 \mathrm{mg} \mathrm{L}^{-1}$. The rooting experiment was carried out in $1 / 2 \mathrm{MS}$ medium without the addition of hormones, using $0.1 \mathrm{mg} \mathrm{L}^{-1} \mathrm{NAA}$ or $1.0 \mathrm{mg} \mathrm{L}^{-1}$ IBA. The highest rate of viability of explants was obtained with $R$. brasiliensis propagation using $1.0 \mathrm{mg} \mathrm{L}^{-1}$ of BAP. Rooting explants showed survival rates higher than $85 \%$. Rooting rates in R. erythroclados was $87 \%$ while in $R$. brasiliensis it was $38 \%$, The highest rates were obtained using $1.0 \mathrm{mg} \mathrm{L}^{-}$ ${ }^{1}$ IBA in $R$. erythroclados. The acclimatization reached survival rates of $75 \%$ when rooted using NAA and $1 / 2$ MS and $86 \%$ when rooted with IBA. In vitro culture shows to be a viable method to propagate greenberries.
\end{abstract}

Keywords: Rubus brasiliensis; Rubus erythroclados; In vitro cultivation; Domestication.

\section{Resumo}

Rubus brasiliensis e Rubus erythroclados são comumente conhecidas como amoreiras-verdes. Este trabalho teve como objetivo testar protocolos de micropropagação in vitro para amoreiras-verdes. $\mathrm{O}$ experimento de multiplicação foi conduzido utilizando BAP nas concentrações de $1 \mathrm{mg} \mathrm{L}^{-1}, 2 \mathrm{mg} \mathrm{L}^{-1}$ e $3 \mathrm{mg} \mathrm{L}^{-1}$. O experimento de enraizamento foi realizado em meio $1 / 2 \mathrm{MS}$ sem adição de hormônios, utilizando $0,1 \mathrm{mg} \mathrm{L}-1$ de ANA ou 1,0 mg L-1 de AIB. A maior taxa de viabilidade dos explantes foi obtida com a propagação de $R$. brasiliensis com 1,0 $\mathrm{mg} \mathrm{L}^{-1}$ de BAP. Explantes de enraizamento apresentaram taxas de sobrevivência superiores a $85 \%$. A taxa de enraizamento em $R$. erythroclados foi de $87 \%$ enquanto em $R$. brasiliensis foi de $38 \%$. As maiores taxas foram obtidas com $1,0 \mathrm{mg} \mathrm{L}^{-1}$ de AIB em $R$. erythroclados. A aclimatação atingiu taxas de sobrevivência de $75 \%$ quando enraizada com ANA e $1 / 2 \mathrm{MS}$ e $86 \%$ quando enraizado com IBA. A cultura in vitro mostra-se um método viável para a propagação de amoreiras-verdes.

Palavras-chave: Rubus brasiliensis; Rubus erythroclados; Cultivo in vitro; Domesticação.

\section{Resumen}

Rubus brasiliensis y Rubus erythroclados se conocen comúnmente como morera verde. Este trabajo tuvo como objetivo probar protocolos de micropropagación in vitro a morera verde. El experimento de multiplicación se realizó utilizando BAP en concentraciones de $1 \mathrm{mg} \mathrm{L}^{-1}, 2 \mathrm{mg} \mathrm{L}^{-1}$ y $3 \mathrm{mg} \mathrm{L}^{-1}$. El experimento de enraizamiento se llevó a cabo en medio $1 / 2 \mathrm{MS}$ sin la adición de hormonas, utilizando $0.1 \mathrm{mg} \mathrm{L}^{-1} \mathrm{NAA}$ o $1.0 \mathrm{mg} \mathrm{L}^{-1}$ IBA. La mayor tasa de viabilidad de explantes se obtuvo con la propagación de $R$. brasiliensis usando $1.0 \mathrm{mg} \mathrm{L}^{-1}$ de BAP. Los explantes de enraizamiento mostraron tasas de supervivencia superiores al $85 \%$. La tasa de enraizamiento en $R$. erythroclados fue del $87 \%$ mientras que en $R$. brasiliensis fue del $38 \%$, las tasas más altas se obtuvieron con $1.0 \mathrm{mg} \mathrm{L}^{-1}$ de AIB en R. erythroclados, la aclimatación alcanzó tasas de supervivencia del $75 \%$ al enraizar con NAA y $1 / 2$ MS y $86 \%$ cuando se arraiga con IBA. El cultivo in vitro demuestra ser un método viable para propagar morera verde.

Palabras clave: Rubus brasiliensis; Rubus erythroclados; Cultivo in vitro; Domesticación. 


\section{Introduction}

In Brazil, 11 species of the genus Rubus are described, six of these occur in the Santa Catarina state and are associated with the Atlantic Forest Biome (Reflora, 2019; Reitz, 1996). The species Rubus brasiliensis Mart. and Rubus erythroclados Mart. are commonly known as whiteberries or greenberries, alluding to the color of the fruits that remain green even when ripe (Bueno, 2015). The fruits have high levels of sugar and a pleasant peculiar flavor, which gives market potential compared to other small fruits (Bueno, Biasi, \& Tofanelli, 2018). Information about the ethno-knowledge of these species in the Santa Catarina South Plateau indicates that although they are much appreciated for their sweet taste and were less acidity than blackberries their consumption is made only in fresh fruits mode, when the fruits are found at random, without the habit of collection for processing (Couto Waltrich, Boff \& Boff, 2017).

Greenberries are not domesticated or cultivated commercially yet, although their potential as an alternative for cultivation and economic exploitation by family farmers, like blackberries. Currently, around 500 ha of blackberries originating from genetic material native from United States are cultivated in the south and southeast of Brazil (Antunes, et al., 2014). This fruit consumption is associated with nutraceutical properties, such as anticarcinogenic compounds (Magalhães, Maciel \& Orsolin, 2017), which are present also in greenberries.

Blackberries are multiplied by rooting steam cuttings, root cuttings and tissue culture using in vitro micropropagation (Antunes \& Raseira 2004; Villa, et al., 2008; Villa, et al., 2010). For greenberries, vegetative propagation studies indicate that multiplication via cuttings is inefficient, whereas in vitro cultivation requires adjustments and further studies (Bueno, 2015). The in vitro propagation of $R$. erythroclados was evaluated by Bueno et al. (2018) who found low rooting rates and paralyzed studies, which highlights the necessity of retake work on development of specific protocols for these species. Micropropagation can provide better seedling uniformity and vigor, increased mass production and better health (Dutra, et al., 2010), in addition to allowing molecular biology work to conserve plant genetic resources (Bakhtiar, Mirjalili, \& Sonboli, 2016). Success in berry tissue culture involves adjusting the types and concentrations of growth regulators in the culture medium, especially the cytokinin and auxin types (Villa, et al., 2006). The objective of this work was to define an in vitro micropropagation protocol for greenberries in order to contribute to the domestication of $R$. brasiliensis and $R$. erythroclados.

\section{Methodology}

This study was based on the quantitative research method (Pereira, et al., 2018) and was developed at the EPAGRI Lages Biotechnology Laboratory, based on the in vitro culture methodology described by George (1993). The vegetative material used in this study came from parent plants of Rubus brasiliensis and R. erythroclados kept in a greenhouse (26 $\left.\pm 2{ }^{\circ} \mathrm{C}\right)$ with intermittent irrigation (Figure 1A). The explants, consisting of nodal segments containing an axillary bud, without leaf and approximately $3 \mathrm{~cm}$, were collected and immediately immersed in water. Asepsis was performed in a laminar flow chamber with $70 \%$ alcohol for 1 minute, followed by 30 minutes in $2 \%$ sodium hypochlorite with drops of Tween® 20 and under constant stirring. After triple washings in water, the nodal segments were sectioned at $1 \mathrm{~cm}$ and transferred to paper bridges in test tubes containing $5 \mathrm{ml}$ of liquid culture medium (Figure 1B). The culture medium consisted of MS medium (Murashige \& Skoog, 1962) supplemented with $1.0 \mathrm{mg} \mathrm{L}^{-1}$ benzylaminopurine (BAP), $0.125 \mathrm{mg} \mathrm{L}^{-1}$ salicylic acid (AAS), $0.25 \mathrm{mg} \mathrm{L}^{-1}$ gibberellic acid (GA 3 ), $30 \mathrm{~g} \mathrm{~L}^{-1}$ sucrose, $0.30 \mathrm{~g} \mathrm{~L}^{-1}$ of reduced glutathione, $\mathrm{pH}$ 5.8. The segments remained in the dark for 72 hours in a growth room and afterwards a $16 \mathrm{~h}$ photoperiod $\left(24 \pm 2^{\circ} \mathrm{C}, 50 \mu \mathrm{mol} \mathrm{m} \mathrm{m}^{2}\right)$. After 40 days, cultures were subcultured in test tubes containing basal medium (MS, $30 \mathrm{~g} \mathrm{~L}^{-1}$ of sucrose, $0.25 \mathrm{mg} \mathrm{L}^{-1} \mathrm{GA}_{3}, 2.6 \mathrm{~g}$ of phytagel and $\mathrm{pH} 5.8$ ) supplemented with $1.0 \mathrm{mg} \mathrm{L}{ }^{-1}$ of BAP. 
Figure 1. In vitro cultivation and propagation of Greenberries. A: Mother plant kept in greenhouse. B: In vitro inclusion. C: Multiplication. D: Rooting ( $\left.1 \frac{1}{2} \mathrm{MS} ; 1 / 2 \mathrm{MS}+0.1 \mathrm{mg} \mathrm{L}^{-1} \mathrm{NAA} ; 1 / 2 \mathrm{MS}+1.0 \mathrm{mg} \mathrm{L}-1 \mathrm{IBA}\right)$.

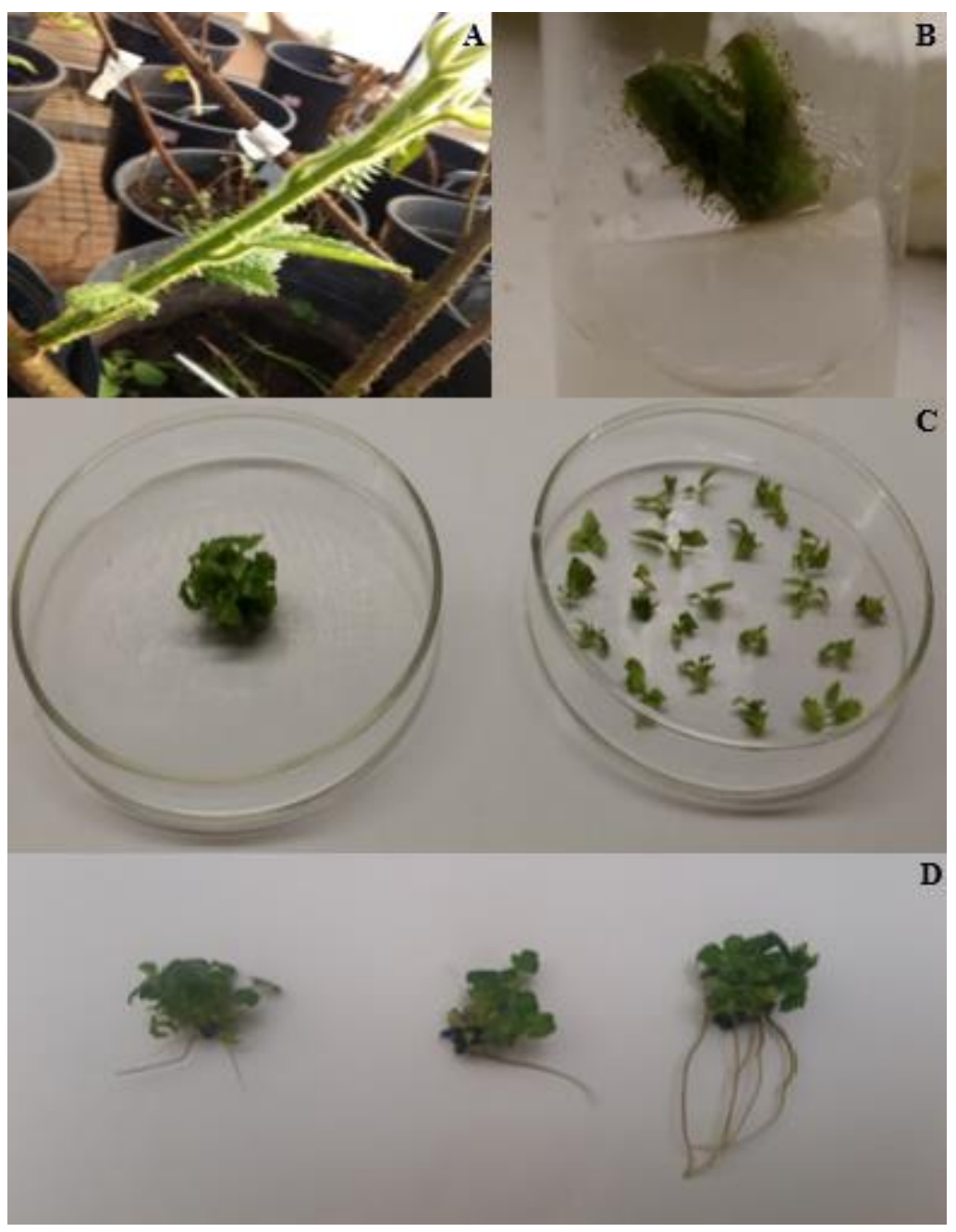

Source: Authors.

The multiplication experiment was carried out in culture flasks containing $30 \mathrm{ml}$ of basal medium in concentrations of BAP at $1 \mathrm{mg} \mathrm{L}^{-1} ; 2 \mathrm{mg} \mathrm{L}^{-1}$ and $3 \mathrm{mg} \mathrm{L}^{-1}$, which constituted the treatments. After 60 days, survival and multiplication rates (Figure 1C) were analyzed. The rooting experiment was carried out in culture flasks containing $30 \mathrm{ml}$ of MS medium with half the concentration of salts ( $1 / 2 \mathrm{MS}$ ), supplemented with $20 \mathrm{~g} \mathrm{~L}^{-1}$ of sucrose, $2.6 \mathrm{~g} \mathrm{~L}^{-1}$ of Phytagel and pH adjusted to 5.8. Treatments were established with addition of $0.1 \mathrm{mg} \mathrm{L}^{-1}$ of a-naphthalene acetic acid (NAA) or $1.0 \mathrm{mg} \mathrm{L}^{-1}$ of indolbutyric acid (IBA) to the medium without growth regulator. After 38 days, survival rates, rooting, length and number of roots were analyzed (Figure 1D).

Acclimatization was carried out by transferring 60 rooted plants to alveolate trays of 128 cells, containing commercial substrate composed of carbonized husks of Pinus sp, vermiculite, chalky and fertilized with N, P and K, sand and rice husks in proportion 1: 1: $1(\mathrm{v} / \mathrm{v} / \mathrm{v})$, arranged inside plastic trays and covered by transparent plastic to maintain humidity.

The experiments were carried out independently for each species of greenberries (R. brasiliensis and R. erythroclados), in a randomized block design, with three replicates of 25 replicates each. The results were submitted to analysis of variance and test of separation of means (Tukey, $\mathrm{p}<0.05)$ using the R environment (R Core Team, 2015). 


\section{Results and Discussion}

The explant survival of in vitro cultures of greenberries did not differ between the tested BAP concentrations (Table 1). The highest rate of viability of explants in R. brasiliensis was obtained using $1.0 \mathrm{mg} \mathrm{L}^{-1}$ of BAP. In the species $R$. erythroclados, the treatments did not differ from each other (Table 1).

Table 1. Survival and multiplication rates of greenberries Rubus brasiliensis and Rubus erythroclados grown in vitro with different concentrations of benzylaminopurine (BAP). Lages/SC, 2020.

\begin{tabular}{lccc}
\hline Species & BAP $\left(\mathrm{mg} \mathrm{L}^{-1}\right)$ & Survival rate $(\%)$ & Multiplication rate $\left(\mathrm{N}^{\mathrm{o}}\right)$ \\
\hline \multirow{2}{*}{ Rubus brasiliensis } & 1,0 & $88 \% \mathrm{~ns}$ & $5,61 \pm 1,58^{\mathrm{a}}$ \\
& 2,0 & $91 \%$ & $3,37 \pm 0,77^{\mathrm{b}}$ \\
& 3,0 & $87 \%$ & $3,93 \pm 1,74^{\mathrm{b}}$ \\
\hline \multirow{2}{*}{ Rubus erythroclados } & 1,0 & $73 \% \mathrm{~ns}$ & $4,79 \pm 0,97 \mathrm{~ns}$ \\
& 2,0 & $85 \%$ & $4,39 \pm 1,01$ \\
& 3,0 & $84 \%$ & $5,61 \pm 2,14$ \\
\hline
\end{tabular}

ns: not significant; averages followed by the same letter do not differ (Tukey, $p \leq 0,05$ ). Source: Authors.

The concentration of $1.0 \mathrm{mg} \mathrm{L}^{-1}$ of BAP was also the most efficient in the multiplication of the blackberry cultivar Xavante (Toledo \& Biasi, 2018) and cv. Ebano (Villa, etal., 2005). On the other hand, for the cultivar Thornless, Najaf-Abadi \& Hamidoghli (2009) found that the combination of $2.0 \mathrm{mg} \mathrm{L}^{-1} \mathrm{BAP}$ and $0.5 \mathrm{mg} \mathrm{L}^{-1} \mathrm{GA}_{3}$ was efficient. Erig, De Rossi \& Fortes (2002) observed that in the Tupy cultivar, the highest multiplication rate was obtained with $0.45 \mathrm{mg} \mathrm{L}^{-1}$ of BAP. Responses to BAP concentrations are related to the species genotypes, as found by Hunková, Libiakova \& Gajdošová (2016) under study with Rubus Black Jewel, Tayberry, Tulameen and Black Satin cultivars. Their results point to multiplication rates between 2.34 and 4.08 in medium with $1 \mathrm{mg} \mathrm{L}^{-1}$ BAP.

Explants of greenberries submitted to rooting showed high survival rates (91\% in Rubus brasiliensis and $85 \%$ in Rubus erythroclados), with no difference between treatments $(\mathrm{p} \leq 0.05)$. The rooting rate presented by $R$. erythroclados explants $(87 \%)$ differed significantly from that presented by Rubus brasiliensis explants (38\%) (Table 2). 
Table 2. Survival, rooting, length and number of roots in greenberries Rubus brasiliensis and Rubus erythroclados in vitro culture.

\begin{tabular}{|c|c|c|c|c|c|}
\hline Species & Treatment & $\begin{array}{c}\text { Survival rate } \\
\qquad \%)\end{array}$ & $\begin{array}{c}\text { Rooting rate } \\
\qquad(\%)\end{array}$ & Root length (mm) & Root number $\left(\mathrm{n}^{\circ}\right)$ \\
\hline \multirow{3}{*}{$\begin{array}{l}\text { Rubus } \\
\text { brasiliensis }\end{array}$} & IBA & $0,98 \%$ ns & $0,38 \%$ ns & $9,13 \pm 3,76^{\mathrm{ns}}$ & $2,25 \pm 1,38^{\mathrm{ns}}$ \\
\hline & MS & $0,90 \%$ & $0,22 \%$ & $9,35 \pm 1,06$ & $1,39 \pm 0,37$ \\
\hline & NAA & $0,88 \%$ & $0,32 \%$ & $6,99 \pm 6,21$ & $1,28 \pm 1,33$ \\
\hline \multirow{3}{*}{$\begin{array}{c}\text { Rubus } \\
\text { erythroclados }\end{array}$} & IBA & $0,92 \%$ ns & $0,87 \%{ }^{\mathrm{a}}$ & $14,91 \pm 3,06^{\mathrm{ns}}$ & $4,54 \pm 0,63^{a}$ \\
\hline & MS & $0,97 \%$ & $0,28 \%$ b & $21,73 \pm 3,18$ & $2,92 \pm 0,14^{b}$ \\
\hline & NAA & $0,92 \%$ & $0,46 \%$ & $17,84 \pm 3,37$ & $2,54 \pm 0,55^{b}$ \\
\hline
\end{tabular}

ns: not significant; averages followed by the same letter do not differ (Tukey, $p \leq 0,05$ ). Source: Authors.

The rate of in vitro rooting obtained in this work for the species $R$. brasiliensis was higher than that obtained by Bueno (2015), which was $16 \%$ and $5 \%$ of rooting using stem and root cuttings, respectively.

The present results point to $75 \%$ survival rates for greenberries on acclimatization when rooted using NAA and 1/2 MS and $86 \%$ when rooted with IBA. The facility on acclimatization of blackberries was described by Toledo \& Biasi (2018) in work with cultivar Xavante.

\section{Conclusion}

Greenberries of the species Rubus brasiliensis and Rubus erythroclados can be propagated through in vitro micropropagation using MS medium with addition of $1.0 \mathrm{mg} \mathrm{L}^{-1}$ of BAP and rooted using $1 / 2 \mathrm{MS}$ culture medium plus 1.0 mg L ${ }^{1}$ IBA. It is necessary to improve the in vitro propagation protocol of Greenberries, especially by testing different concentrations of hormones in the culture medium. Thus, this protocol can contribute to the domestication process and the consequent preservation of these species forgotten until now.

\section{Acknowledgments}

This Research was supported by "Fundação de Amparo e Pesquisa do Estado de Santa Catarina" FAPESC (Rede Guarani Serra Geral, conv. FAPESC/2015/TR1067) and "Conselho Nacional de Desenvolvimento Cientifico e Tecnológico" CNPq (productivity grants 304018/2015 and 307376/2017-6).

\section{References}

Antunes, L. E. C., Pereira, I. D. S., Picolotto, L., Vignolo, G. K. \& Gonçalves, M. A. (2014). Produção de amoreira-preta no Brasil. Revista Brasileira de Fruticultura, 36 (1), 100-111. 10.1590/0100-2945-450/13.

Antunes, L. E. C. \& Rasseira, M. C. B. (2004). Aspectos técnicos da cultura da amora-preta. Embrapa.

Bakhtiar, Z., Mirjalili, M. H. \& Sonboli, A. (2016). In vitro callus induction and micropropagation of Thymus persicus (Lamiaceae), an endangered medicinal plant. Crop Breeding and Applied Biotechnology, 16 (1), 48-54https://doi.org/10.1590/1984-70332016v16n1a8.

Bueno, P. M. C. (2015). Propagação vegetativa de espécies de amoreira-verde (Rubus erythroclados Martius e Rubus brasiliensis Martius). (Tese de doutorado). Universidade Federal do Paraná, Curitiba, Paraná. 69p.

Bueno, P. M. C., Biasi, L. A. \& Tofanelli, M. B. D. (2018). Micropropagation protocol for the wild Brazilian greenberry (Rubus erythroclados). Revista Colombiana de Ciencias Hortícolas, 12 (2), 405-415. https://doi.org/10.17584/rcch.2018v12i2.7226. 
Couto Waltrich, C., Boff, P. \& Boff, M. I. C. (2017). Etnoconhecimento associado às amoreiras-brancas (Rubus spp.) ocorrentes na Floresta Ombrófila Mista, Santa Catarina, Brasil. Revista de la Facultad de Agronomía,116 (1), 13-18. http://sedici.unlp.edu.ar/handle/10915/61783

Dutra, L. F., Silva, N. D. G., Mayer, K. C. A., Nino, A. F. P., Silva, F. O. X. \& Vieira, F. C. B. (2010). Protocolos de micropropagação de plantas II: amoreirapreta. Embrapa Clima Temperado Pelotas, RS.

Erig, A. C., De Rossi, A. \& Fortes, G. R. L. (2002). 6-benzilaminopurina e ácido indolbutírico na multiplicação in vitro da amoreira-preta (Rubus idaeus L.), cv. Tupy. Ciência Rural, 32 (5), 765-770. https://doi.org/10.1590/S0103-84782002000500005.

George, E. F., Hall, M. A. \& Klerk, G. J. (1993). Plant propagation by tissue culture: Part 1: The technology. London, England: Exegetics Ltd.

Hunkova, J., Libiakova, G. \& Gajdošová, A. (2016). Shoot proliferation ability of selected cultivars of Rubus spp. as influenced by genotype and cytokinin concentration. Journal of Central European Agriculture, 17 (2), 379-390. https://doi.org/10.5513/JCEA01/17.2.1718.

Magalhães, M. D., Maciel, A. D. \& Orsolin, P. C. (2017). Efeito anticarcinogênico dos flavonoides do tipo antocianina presentes em amora-preta (Rubus spp.), identificado por meio do teste para detecção de clones de tumores epiteliais (wts) em Drosophila melanogaster. Revista de Medicina e Saúde de Brasília, 6 (1), 5-14. https://portalrevistas.ucb.br/index.php/rmsbr/article/view/7530

Murashige, T. \& Skoog, F. (1962). A resived medium for rapid growth and bioassays with tobacco tissue cultures. Physiologia Plantarum, 15 (3), $473-497$. https://doi.org/10.1111/j.1399-3054.1962.tb08052.x

Najaf-Abadi, A. J. \& Hamidoghli, Y. (2009). Micropropagation of thornless trailing blackberry (Rubus sp.) by axillary bud explants. Australian Journal of Crop Science, 3 (4), 191-194. https://search.informit.com.au/documentSummary;dn=037509152756777;res=IELHSS

Pereira A. S., Shitsuka D. M., Parreira, F. J. \& Shitsuka R (2018). Metodologia da pesquisa científica. UAB / NTE / UFSM. https://repositorio.ufsm.br/bitstream/handle/1/15824/Lic_Computacao_Metodologia-Pesquisa-Cientifica.pdf?sequence=1

R Core Team. (2015). R: a language and environment for statistical computing. Version 3.1. 2. R Foundation for Statistical Computing.

Reflora. (2020). Rosaceae in Flora do Brasil 2020 em construção. Jardim Botânico do Rio de Janeiro. http://reflora.jbrj.gov.br/reflora/floradobrasil/FB20678

Reitz, R. (1996). Flora ilustrada catarinense, as plantas rosa. Monografia. Itajaí, Santa catarina. 135p.

Toledo, J. A. \& Biasi, L. A. (2018). Multiplicação e enraizamento in vitro da amoreira preta cv. Xavante. Cultura Agronômica: Revista de Ciências Agronômicas, 27 (3), 328-339. https://doi.org/10.32929/2446-8355.2018v27n3p328-339

Villa, F., Araújo, A. D., Pio, L. A. S. \& Pasqual, M. (2005). Multiplicação in vitro da amoreira-preta 'Ébano' em diferentes concentrações de meio MS e BAP. Ciência e Agrotecnologia, 29 (3), 582-589. https://doi.org/10.1590/S1413-70542005000300011

Villa, F., Pasqual, M., De Assis, F. A., Pio, L. A. S. \& De Assis, G. A. (2008). Crescimento in vitro de amoreira-preta: efeito de reguladores de crescimento e da cultivar. Ciência e Agrotecnologia, 32 (6), 1754-1759. https://doi.org/10.1590/S1413-70542008000600012

Villa, F., Pasqual, M., Das Graças Souza, A. \& De Souza Vilela, X. M. (2010). Meios de cultura e reguladores de crescimento na multiplicação in vitro de amoreira-preta. Scientia Agraria, 11 (2), 109-117. https://www.redalyc.org/pdf/995/99515218003.pdf

Villa, F., Pasqual, M., Pio, L. A. S., Teodoro, G. S. \& Miyata, L. Y. (2006). Multiplicação in vitro de amoreira-preta 'cherokee': efeito de meios de cultura, cinetina e $\mathrm{GA}_{3}$ in vitro. Ceres, 53 (307), 357-362. https://www.redalyc.org/pdf/3052/305226699011.pdf 